\title{
Species-Specific PCR Assays for Differentiating Heterodera filipjevi and $H$. avenae
}

Guiping Yan and Richard W. Smiley, Oregon State University, Columbia Basin Agricultural Research Center, Pendleton 97801; Patricia A. Okubara, United States Department of Agriculture-Agricultural Research Service (USDA-ARS), Root Disease and Biological Control Research Unit, Pullman, WA 99164-6430; and Andrea M. Skantar, USDA-ARS, Nematology Laboratory, Beltsville, MD 20705

\begin{abstract}
Yan, G. P., Smiley, R. W., Okubara, P. A., and Skantar, A. M. 2013. Species-specific PCR assays for differentiating Heterodera filipjevi and H. avenae. Plant Dis. 97:1611-1619.

Heterodera avenae and $H$. filipjevi are economically important cyst nematodes that restrict production of cereal crops in the Pacific Northwest United States and elsewhere in the world. Identification of these two species is critical for recommending and implementing effective management practices. Primers were designed from the internal transcribed spacer (ITS) regions of $H$. avenae and $H$. filipjevi ribosomal DNA. The primers were highly specific when examined on target isolates but did not amplify DNA from nontarget Heterodera, Globodera, Meloidogyne, Pratylenchus, and other nematode species tested. Polymerase chain reaction (PCR) and amplification conditions were estab-

lished, and $H$. avenae and $H$. filipjevi were clearly distinguished by PCR fragments of 242 and $170 \mathrm{bp}$, respectively. Robust PCR amplification was achieved with DNA extracted from a single egg or secondstage juvenile (J2) using a laboratory-made worm lysis buffer, and DNA from 0.5 egg or J2 using a commercial kit. The PCR assays were successfully employed for differentiation of $H$. filipjevi and $H$. avenae populations collected from eight locations in three Pacific Northwest states. This is the first report of a species-specific ITS PCR assay to detect and identify $H$. filipjevi. The assays for both species will enhance diagnosis of cereal cyst nematode species in infested fields.
\end{abstract}

The cereal cyst nematodes $(\mathrm{CCN})$ are a widespread and important group of sedentary plant-parasitic nematodes that restrict production of cereal crops throughout the world (22). The cyst nematode genus Heterodera includes more than 60 species (42). Twelve species in the Heterodera avenae complex (10) infect roots of cereals and grasses. Three of them- $H$. avenae Wollenweber, 1924; H. filipjevi (Madzhidov, 1981) Stone, 1985; and H. latipons Franklin, 1969-are considered to be the most economically important cyst nematodes that affect cultivated cereals worldwide $(15,22,25)$.

In the United States, four species of $\mathrm{CCN}(H$. avenae, H. filipjevi, $H$. mani, and H. ustinovi $[=H$. iri]) have been reported but only two of them (H. avenae and $H$. filipjevi) are parasitic to wheat and known to be present in Pacific Northwest (PNW) fields (44). H. ustinovi is not associated with wheat and $H$. mani does not reproduce readily on wheat (33), and these two species have not been reported in PNW fields (R. Ingham, Oregon State University, Corvallis, personal communication). H. avenae was first detected in Oregon in 1974 (13) and is now known to occur in at least seven western states, including three PNW states: Idaho, Oregon, and Washington (7-9,25,26,30). High populations of $H$. avenae reduced yields of susceptible wheat cultivars as much as $50 \%(25,26,30)$. It was estimated that this nematode reduces the profit from wheat production by at least $\$ 3.4$ million annually in the PNW (25). The first detection of $H$. filipjevi in the United States was in Oregon during $2008(31,43)$. The extent to which $H$. filipjevi occurs in the western United States remains

\section{Corresponding author: G. P. Yan, E-mail: guiping.yan@ oregonstate.edu}

Mention of trade names or commercial products in this publication is solely for the purpose of providing specific information and does not imply recommendation or endorsement by the United States Department of Agriculture.

Accepted for publication 24 June 2013.

http://dx.doi.org/10.1094/PDIS-01-13-0064-RE

(C) 2013 The American Phytopathological Society unclear because there have been no systematic nematode surveys for this species.

$H$. filipjevi is closely related to $H$. avenae in the $H$. avenae group complex and morphological differences among cysts and secondstage juveniles (J2s) are very minor (10,33). Distinction between $H$. avenae and $H$. filipjevi using microscopic procedures is time consuming, requires skill and training, and is frequently inconclusive because individual specimens may vary greatly within a population (44). Due to this complexity and the potential economic liability, commercial laboratories in the PNW routinely identify $\mathrm{CCN}$ only to the genus level. They report "Heterodera spp." but do not differentiate $H$. avenae from $H$. filipjevi. Precise identification of species is important for recommending and implementing effective management practices (e.g., selection of resistant or tolerant cultivars requires knowledge of the identity of individual species because such cultivars are not necessarily resistant or tolerant to both species) (16).

Molecular techniques offer more rapid and accurate alternatives for distinguishing species of cyst nematodes than morphological identification $(4,5,23,32,36)$. Polymerase chain reaction-restriction fragment length polymorphism (PCR-RFLP) based on the internal transcribed spacer (ITS) region of the ribosomal DNA (rDNA) repeat unit has facilitated quick and precise identification of plantparasitic nematode species, including cyst nematode species and subspecies $(1,5,14,23,31,34,35,39,41)$. A PCR-RFLP protocol was previously reported to discriminate the species of Heterodera populations collected from PNW infested fields based on cleavage by up to six restriction endonucleases (44). Because PCR-RFLP requires the additional restriction cleavage step with combinations of several enzymes $(23,33,44)$, a single-step PCR using speciesspecific primers is preferable.

Single-step PCR amplification with species-specific primers has been used for identification of several cyst nematodes such as $H$. latipons, $H$. glycines, $H$. schachtii, $H$. avenae, and $H$. filipjevi without need for a subsequent RFLP step $(4,19,20,32,37,38)$. A commercial diagnostic laboratory, South Australia Research and Development Institute, uses a proprietary species-specific real-time PCR procedure to identify and quantify $H$. avenae along with two rootlesion nematode species and six fungal pathogens of wheat in 
DNA extracted from soil $(11,18,21,38)$. Toumi et al. (38) targeted the mitochondrial cytochrome oxidase subunit 1 (COI) gene and developed two species-specific primer sets to detect $H$. avenae and $H$. filipjevi. Peng et al. (20) detected and identified $H$. filipjevi using species-specific sequence-characterized amplified region (SCAR) primers designed from randomly amplified polymorphic DNA markers. However, there are no published reports of a species-specific PCR assay using the ITS region of rDNA to detect and identify $H$. filipjevi and $H$. avenae and distinguish them from other closely related Heterodera spp. An increasing number of ITS sequences are now available from GenBank, which allows specificity of ITS PCR primers to be assessed by sequence analyses performed in silico using a computer program and many known DNA sequences from public databases $(6,17,24,45-47)$.

The objectives of this study were to (i) develop species-specific ITS PCR assays for detection and differentiation of $H$. filipjevi and $H$. avenae that would also distinguish them from other nontarget Heterodera spp. and other nematode species commonly present in PNW wheat fields, (ii) compare the predictions of primer specificity from in silico analysis with PCR test results and expand specificity evaluation to additional nematode species and isolates that were not available in the format of culture or DNA, and (iii) determine whether the assays were useful for detecting populations of these nematodes in PNW field soils.

\section{Materials and Methods}

Cyst extraction from soil and DNA extraction from nematodes. Cyst-nematode-infested soil was placed on the top of a set of sieves consisting of 710-, 425-, and 250- $\mu \mathrm{m}$-pore sieves. Brown cysts were extracted from the soil using the sieving-decanting method (12). Cysts collected on the bottom sieve $(250 \mu \mathrm{m})$ were picked up with a dissecting needle under a stereomicroscope, transferred to an Eppendorf tube containing sterilized water, and stored at $4{ }^{\circ} \mathrm{C}$ for nematode identification. The cysts were poked open with the needle and intact eggs and juveniles were used for DNA extraction. Approximately 20 eggs or J2s were transferred in $20 \mu \mathrm{l}$ of sterilized nanopure water using a glass pipette, placed on a concave glass slide, and cut into pieces under a microscope. DNA was extracted from these nematodes using the method described by Yan and Smiley (44) and Waeyenberge et al. (40). The nematode suspension containing the majority of nematode pieces $(10 \mu \mathrm{l})$ was transferred to a $0.5-\mathrm{ml}$ sterile tube with $8 \mu \mathrm{l}$ of worm lysis buffer (500 mM KCl, $100 \mathrm{mM}$ Tris- $\mathrm{HCl}$ [pH 8.3], $15 \mathrm{mM} \mathrm{MgCl}_{2}, 10 \mathrm{mM}$ dithiothreitol, $4.5 \%$ Tween 20 , and $0.1 \%$ gelatin). The contents were immediately frozen and kept at $-20^{\circ} \mathrm{C}$ for at least $20 \mathrm{~min}$. The nematode suspension was thawed and $2 \mu \mathrm{l}$ of proteinase $\mathrm{K}$ at $600 \mu \mathrm{g} / \mathrm{ml}$ was added into each sample. Three samples were included for each $H$. filipjevi or $H$. avenae population. Proteinase $\mathrm{K}$ was carried out at $65^{\circ} \mathrm{C}$ for $1 \mathrm{~h}$; then, the enzyme was inactivated at $95^{\circ} \mathrm{C}$ for $10 \mathrm{~min}$. The nematode lysis mix was centrifuged at $16,000 \times g$ for 3 min to remove nematode debris. The supernatant was transferred to a clean $0.5-\mathrm{ml}$ tube and frozen at $-20^{\circ} \mathrm{C}$ until used for the following PCR amplification. DNA was quantified using the NanoDrop ND-1000 Spectrophotometer.

Design of species-specific PCR primers. Ten primers for $\mathrm{H}$. filipjevi and eight primers for $H$. avenae were designed using an alignment of Heterodera ITS sequences of rDNA obtained from GenBank. The alignment consisted of sequences from 25 accessions: $5 \mathrm{H}$. filipjevi (GU079654, AY148398, AY148399, AY148403, and AY148401), 8 H. avenae (EF153843, AY148353,
AY148355, AY148362, AY148364, AY148365, AY148369, and AY148374), 1 H. arenaria (AF274396), 2 H. mani (AY148375 and AY148378), 3 H. aucklandica (AF274398, AY148379, and AY148380), 2 H. pratensis (AY148391 and AY148388), 2 H. australis (AY148393 and AY148396), and 2 H. ustinovi (AY148406 and AY148407). The primers were analyzed for annealing temperature, GC content, hairpin, self-dimer, and heterodimer using OligoAnalyzer 3.1 (Integrated DNA Technologies, Inc.) and synthesized by Invitrogen. The performance of these primers was evaluated with two isolates each of $H$. filipjevi and $H$. avenae based on PCR band intensity and specificity. The sequences of the bestperforming primers (HfITS-F1 and HfITS-R1 for $H$. filipjevi and HaITS-F6 and HaITS-R4 for H. avenae) and their expected sizes of the PCR products are shown in Table 1. These two primer pairs were used for all experiments.

Evaluation of primer specificity. Four isolates of $H$. filipjevi from the United States, Turkey, and Iran and five isolates of $H$. avenae from the United States and Syria were used to test the specificity of the primers (Table 2). Eight other Heterodera spp. that were used as nontarget species included H. latipons, $H$. ciceri, $H$. glycines, $H$. goettingiana, $H$. hordecalis, $H$. lespedezae, $H$. schachtii, and $H$. zeae (Table 2). The specificity was also examined with eight isolates of Pratylenchus spp. (Pratylenchus neglectus, $P$. penetrans, $P$. thornei, and P. zeae), five isolates of Globodera spp. (Globodera ellingtonae, G. pallida, G. rostochiensis, G. tabacum solanacearum, and $G$. tabacum tabacum), six isolates of Meloidogyne spp. (Meloidogyne arenaria, M. chitwoodi, M. hapla, $M$. incognita, and $M$. naasi), one isolate of Nacobbus aberrans, and three isolates of other plant-parasitic nematode species (Merlinius brevidens, Tylenchorhynchus sp., and Paratylenchus sp.) that were commonly present in PNW wheat fields.

In silico analysis. The ITS sequences of some reference Heterodera spp. were available on the National Center for Biotechnology Information databases (http://www.ncbi.nlm.nih.gov/). The experimental PCR responses from the reference species were compared with those predicted by in silico analysis using the computer program PrimerSelect 5.00 (DNASTAR, Inc.). Seven reference Heterodera spp. were compared in this study, including $H$. avenae from the United States (JX024195 and EF153843), H. filipjevi from the United States (GU079654) and Turkey (JX024203 and JX024204), H. ciceri from Syria (JX024201), H. hordecalis from Italy (AY347924), H. latipons from Syria (JX024178), H. schachtii from France (EF611103), and H. zeae from Greece (GU145616) (Table 3).

To further predict the specificity of the primers to ITS sequences of additional nematode species and isolates or DNA that could not be obtained upon request, in silico analysis was also conducted using ITS sequences of 50 Heterodera accessions from GenBank (Table 3) and the PrimerSelect 5.00 (DNASTAR, Inc.). The ITS sequences included nine isolates of $H$. avenae; six isolates of $H$. filipjevi; four isolates each of $H$. pratensis and $H$. schachtii; three isolates each of $H$. aucklandica, $H$. bifenestra, $H$. hordecalis, $H$. latipons, H. mani, and H. ustinovi; two isolates each of $H$. australis, $H$. ciceri, and $H$. glycines; and one isolate each of $H$. arenaria, $H$. iri, and $H$. turcomanica from 20 countries (Table 3 ). The specificity of the primers to the sequences of Heterodera spp. was determined by primer-template duplex stability values $(\Delta \mathrm{G})$ as described by Schroeder et al. (24), Okubara et al. (17), and Yan et al. (45-47).

PCR assay. PCR reactions $(25 \mu \mathrm{l})$ consisted of the DNA template $(8.7 \mathrm{ng} / \mu \mathrm{l}), 1 \times$ PCR buffer $(10 \mathrm{mM}$ Tris- $\mathrm{HCl}, 1.5 \mathrm{mM}$

Table 1. Sequences of species-specific polymerase chain reaction (PCR) primers designed in this study and the expected size of PCR amplicons to differentiate Heterodera filipjevi and H. avenae

\begin{tabular}{lllc}
\hline Species & Primer name $^{\mathbf{a}}$ & \multicolumn{1}{c}{ Sequence $_{\left(\mathbf{5}^{\prime} \mathbf{- 3}\right)}$ ) } & Amplicon size (bp) \\
\hline H. filipjevi & F: HfITS-F1 & CCCGTCTGCTGTTGAGA & 170 \\
H. avenae & R: HfITS-R1 & ACCTCAGGCTTTTATTATCAC & $\ldots$ \\
& F: HaITS-F6 & ATGCCCCCGTCTGCTGA & 242 \\
\hline
\end{tabular}

${ }^{\mathrm{a}} \mathrm{F}=$ forward primer and $\mathrm{R}=$ reverse primer. 
$\mathrm{MgCl}_{2}$, and $50 \mathrm{mM} \mathrm{KCl}, \mathrm{pH}$ 8.3), $0.2 \mathrm{mM}$ dNTPs, $1 \times$ Cresol Red in $20 \%$ glycerol, $0.5 \mu \mathrm{M}$ each forward and reverse primer, and 0.75 $\mathrm{U}$ of Taq polymerase (Roche). PCR amplification was carried out in a MyCycler Thermal Cycler (Bio-Rad) using the following program: one initial cycle of denaturation at $95^{\circ} \mathrm{C}$ for $3 \mathrm{~min} ; 35$ cycles of $95^{\circ} \mathrm{C}$ for $30 \mathrm{~s}, 58^{\circ} \mathrm{C}$ (HfITS-F1/HfITS-R1) or $64^{\circ} \mathrm{C}$ (HaITS-F6/HaITS-R4) for $30 \mathrm{~s}$, and $72^{\circ} \mathrm{C}$ for $30 \mathrm{~s}$; and a final extension of $72^{\circ} \mathrm{C}$ for $7 \mathrm{~min}$. PCR products were partitioned on $2 \%$ agarose gel using $0.5 \times$ Tris-borate-EDTA buffer $(45 \mathrm{mM}$ Trisborate and $2 \mathrm{mM}$ EDTA, $\mathrm{pH}$ 8.0), and stained with ethidium bromide. Amplicon sizes were extrapolated using a 100-bp DNA ladder (Roche). Band pattern was visualized and photographed under UV light using a Polaroid digital camera, and analyzed by the Polaroid PhotoMAX Pro program (Polaroid).

To confirm the quality of DNA templates from the nontarget nematode species (Table 2) provided by L. Waeyenberge and F. Toumi (Belgium), R. Rivoal (France), and A. Skantar, the D3 region of the 28S rDNA was amplified using primers D3A $\left(5^{\prime}-\right.$ GACCCGTCTTGAAACACGGA-3') and D3B (5'-TCGGAA GGAACCAGCTACTA-3') (2,3). PCR was conducted as described above for the species-specific PCR, using PCR amplification conditions as follows: one initial cycle of denaturation for $2 \mathrm{~min}$ at $94^{\circ} \mathrm{C}$; followed by 40 cycles of $30 \mathrm{~s}$ at $94^{\circ} \mathrm{C}, 1 \mathrm{~min}$ at $55^{\circ} \mathrm{C}$, and 2 min at $72^{\circ} \mathrm{C}$; with a final extension of $7 \mathrm{~min}$ at $72^{\circ} \mathrm{C}$.
Detection sensitivity of PCR amplification. Different populations of $H$. filipjevi or $H$. avenae eggs $(n=0,1,2,3,4,5,10,15$, and 29) were transferred in $20 \mu \mathrm{l}$ of sterilized nanopure water using a glass pipette. One $\mathrm{J} 2$ was hand-picked using a dental pick and put into $20 \mu \mathrm{l}$ of sterilized water. Nematode DNA was extracted using the worm lysis buffer described above to determine the minimum number of nematode individuals detectable in the PCR assays. Twofold serial dilutions of a single nematode DNA (1:1, 1:2, 1:4, $1: 8,1: 16,1: 32,1: 64$, and 1:128) were also used to test the sensitivity, with or without bovine serum albumin (BSA; Roche) at 0.8 $\mu \mathrm{g} / \mu \mathrm{l}$, in PCR reactions. For comparison with extraction using a commercial kit, $H$. filipjevi and $H$. avenae eggs $(n=0,1$, and 2$)$ and J2s ( $n=0$ and 1$)$ were added separately to PowerBead tubes provided with the PowerSoil DNA Isolation Kit (MoBio), and DNA was extracted according to the manufacturer's recommendations. A low number of $H$. filipjevi and $H$. avenae $(0.5$ egg or $0.5 \mathrm{~J} 2$ ) was also attempted; one egg or one $\mathrm{J} 2$ was cut in the middle into two pieces with a dissecting needle under a microscope and both pieces ( 0.5 of a body) were used separately for DNA extraction using the kit. The DNA extractions were replicated four times using the worm lysis buffer and three times using the commercial kit for each population. PCR was performed in duplicate for each independent DNA extraction. The sensitivity for PCR detection was determined as the minimum number of eggs or

Table 2. Isolates of Heterodera spp. and other nematode species used to test the species-specific polymerase chain reaction primers for differentiating Heterodera filipjevi and $H$. avenae

\begin{tabular}{|c|c|c|c|c|}
\hline Species & Isolate code & Origin & Host & Source $^{a}$ \\
\hline H. filipjevi & Hf1 & Oregon, United States & Wheat & G. Yan \\
\hline H. filipjevi & $\mathrm{Hf} 2$ & Eskisehir, Turkey & Wheat & L. Waeyenberge \\
\hline H. filipjevi & Hf3 & Merkez, Turkey & Wheat & L. Waeyenberge \\
\hline H. filipjevi & Hf 4 & Lorestan, Iran & Wheat & L. Waeyenberge \\
\hline H. avenae & Ha1 & Oregon, United States & Wheat & R. Smiley \\
\hline H. avenae & $\mathrm{Ha} 2$ & Oregon, United States & Wheat & R. Smiley \\
\hline H. avenae & $\mathrm{Ha} 3$ & Idaho, United States & Wheat & R. Smiley \\
\hline H. avenae & Ha4 & Washington, United States & Wheat & R. Smiley \\
\hline H. avenae & Ha5 & Syria & Wheat & F. Toumi \\
\hline H. latipons & Hla1 & Syria & Wheat & F. Toumi \\
\hline H. latipons & Hla2 & Iran & Wheat & L. Waeyenberge \\
\hline H. ciceri & $\mathrm{FaC} 3$ & Syria & Chickpea & F. Toumi \\
\hline H. glycines & 27B1 & Maryland, United States & Soybean & A. Skantar \\
\hline H. goettingiana & Vacirca cyst 1 & Italy & Wheat & A. Skantar \\
\hline H. hordecalis & Giurffo cyst 6 & Italy & Wheat & A. Skantar \\
\hline H. lespedezae & $6 \mathrm{~A} 2$ & Egypt & Sorghum & A. Skantar \\
\hline H. schachtii & Hs & Laon, France & Sugar beet & R. Rivoal \\
\hline H. zeae & $48 \mathrm{C} 1$ & Greece & Corn & A. Skantar \\
\hline Globodera ellingtonae & $45 \mathrm{E} 11$ & Oregon, United States & Potato & A. Skantar \\
\hline G. pallida & 22D3 & Idaho, United States & Potato & A. Skantar \\
\hline G. rostochiensis & $27 \mathrm{~A} 12$ & NY, United States & Potato & A. Skantar \\
\hline G. tabacum solanacearum & $27 \mathrm{C} 3$ & Virginia, United States & Tobacco & A. Skantar \\
\hline G. tabacum tabacum & 27E3 & Connecticut, United States & Tobacco & A. Skantar \\
\hline Meloidogyne arenaria & $12 \mathrm{H} 8$ & Maryland, United States & Tomato & A. Skantar \\
\hline M. arenaria & $34 \mathrm{H} 6$ & DE, United States & Traveler's tree & A. Skantar \\
\hline M. chitwoodi & $13 \mathrm{C} 8$ & Oregon, United States & Potato & A. Skantar \\
\hline M. hapla & 6L6 & Canada & Rose & A. Skantar \\
\hline M. incognita & $12 \mathrm{~J} 4$ & Maryland, United States & Tomato & A. Skantar \\
\hline M. naasi & $12 \mathrm{C} 1$ & Oregon, United States & Wheat & A. Skantar \\
\hline Merlinius brevidens & $\mathrm{Mb}$ & Oregon, United States & Wheat & S. Easley \\
\hline Nacobbus aberrans & 38D1 & Peru & Potato & A. Skantar \\
\hline Paratylenchus sp. & $\mathrm{Pa}$ & Oregon, United States & Wheat & G. Yan \\
\hline Pratylenchus neglectus & Pn1 & Washington, United States & Wheat & R. Smiley \\
\hline P. neglectus & Pn2 & Oregon, United States & Wheat & R. Smiley \\
\hline$P$. neglectus & Pn3 & Idaho, United States & Wheat & R. Smiley \\
\hline P. neglectus & Pn4 & Montana, United States & Wheat & A. Dyer \\
\hline$P$. penetrans & $31 \mathrm{H} 12$ & Maryland, United States & Corn & A. Skantar \\
\hline P. thornei & Pt1 & Oregon, United States & Wheat & R. Smiley \\
\hline P. thornei & Pt2 & Oregon, United States & Wheat & R. Smiley \\
\hline P. zeae & $22 \mathrm{G} 8$ & Singapore & Spider lily & A. Skantar \\
\hline Tylenchorhynchus sp. & Ту & Oregon, United States & Wheat & S. Easley \\
\hline
\end{tabular}

a Isolates were obtained from R. Smiley, G. Yan, and S. Easley, Oregon State University, Columbia Basin Agricultural Research Center, Pendleton; L. Waeyenberge and F. Toumi, Institute for Agricultural and Fisheries Research, Plant Sciences Unit-Crop Protection, Merelbeke, Belgium; R. Rivoal, INRA, Rennes, France; A. Dyer, Montana State University, Bozeman; or the frozen nematode collection of A. Skantar, United States Department of AgricultureAgricultural Research Service, Nematology Laboratory, Beltsville, MD. 
J2s of $H$. filipjevi or $H$. avenae producing an amplicon on agarose gels.

Identification of $\boldsymbol{H}$. filipjevi and $\boldsymbol{H}$. avenae from field soil. Thirty soil samples were collected from various wheat fields or fields with recent wheat rotation in the cropping systems. These fields were thought to be infested with $H$. filipjevi or $H$. avenae based upon the symptoms of patches of stunted or uneven wheat growth during our searches for field research sites to screen wheat cultivars for resistance and tolerance. These locations included farms near Cashup, Colfax, Palouse, and Steptoe in Washington; Cove, Imbler, and Island City in Oregon; and St. Anthony in Idaho (Table 4). Samples consisted of a pool of either 50 soil cores (2.5

Table 3. Heterodera spp. and GenBank accession number of internal transcribed spacer (ITS) sequences used for analysis of primer-template duplex stability $(\Delta \mathrm{G})$ for predicting the specificity of primers (HfITS-F1/ HfITS-R1) for Heterodera filipjevi and primers (HaITS-F6/HaITS-R4) for H. avenae

\begin{tabular}{|c|c|c|c|c|c|c|c|}
\hline \multirow[b]{2}{*}{ Species } & \multirow[b]{2}{*}{ GenBank number } & \multirow[b]{2}{*}{ Isolate, clone ${ }^{b}$} & \multirow[b]{2}{*}{ Origin } & \multicolumn{4}{|c|}{$\Delta \mathbf{G}(\mathrm{kcal} / \mathrm{mol})^{\mathrm{a}}$} \\
\hline & & & & HfITS-F1 & HfITS-R1 & HaITS-F6 & HaITS-R4 \\
\hline H. avenae & AY148353 & Clone 1 & Germany & ins & ins & -36.9 & -34.1 \\
\hline H. avenae & AY148355 & Clone 4 & Spain & ins & ins & -36.9 & -34.1 \\
\hline H. avenae & AY148362 & Clone 1 & India & ins & ins & -36.9 & -34.1 \\
\hline H. avenae & AY148364 & Clone 1 & Turkey & ins & ins & -36.9 & -34.1 \\
\hline H. avenae & AY148365 & Clone 1 & Israel & ins & ins & -36.9 & -34.1 \\
\hline H. avenae & AY148369 & Clone 1 & Morocco & ins & ins & -36.9 & -34.1 \\
\hline H. avenae & AY148374 & Clone 5 & France & ins & ins & -36.9 & -34.1 \\
\hline H. avenae & GU595424 & GS23 & China & ins & ins & -36.9 & -31.2 \\
\hline H. avenae & JN831608 & $\mathrm{XJ} 1$ & China & ins & ins & -36.9 & -31.2 \\
\hline H. avenae & JX024195 & $\operatorname{Did} 49$ & United States & ins & ins & -36.9 & -34.1 \\
\hline H. avenae $\mathrm{c}$ & EF153843 & N/A & Idaho, United States & ins & ins & -36.9 & -34.1 \\
\hline H. filipjevi & AY148399 & Clone 1 & Spain & -32.6 & -36.2 & ins & ins \\
\hline H. filipjevi & AY148400 & N/A & Germany & -32.6 & -36.2 & ins & ins \\
\hline H. filipjevi & AY148401 & N/A & Russia & -32.6 & -36.2 & ins & ins \\
\hline H. filipjevi & AY148402 & N/A & Tajikistan & -32.6 & -36.2 & ins & ins \\
\hline H. filipjevi & AY148403 & N/A & United Kingdom & -32.6 & -36.2 & ins & ins \\
\hline H. filipjevi & HM208382 & HN32 & China & -32.6 & -36.2 & ins & ins \\
\hline H. filipjevi ${ }^{\mathrm{c}}$ & GU079654 & Clone 1 & Oregon, United States & -32.6 & -36.2 & ins & ins \\
\hline H. filipjevi $i^{\mathrm{c}}$ & JX024203 & $\operatorname{Did} 42 \mathrm{c}$ & Turkey & -32.6 & -36.2 & ins & ins \\
\hline H. filipjevic & JX024204 & Did42b & Turkey & -32.6 & -36.2 & ins & ins \\
\hline H. arenaria & AF274396 & N/A & United Kingdom & ins & ins & -36.9 & -34.1 \\
\hline H. aucklandica & AF274398 & N/A & New Zealand & ins & ins & -36.9 & -34.1 \\
\hline H. aucklandica & AY148379 & N/A & Belgium & ins & ins & -36.9 & -34.1 \\
\hline H. aucklandica & AY 148380 & Clone 1 & United Kingdom & ins & ins & -36.9 & -34.1 \\
\hline H. australis & AY148393 & Clone 1 & Australia & ins & ins & -36.9 & -31.2 \\
\hline H. australis & AY148396 & Clone 2 & Australia & ins & ins & -36.9 & -31.2 \\
\hline H. bifenestra & AF274384 & N/A & Sweden & ins & ins & ins & ins \\
\hline H. bifenestra & AF274385 & N/A & Belgium & ins & ins & ins & ins \\
\hline H. bifenestra & AY569020 & N/A & Sweden & ins & ins & ins & ins \\
\hline H. ciceri & AF274393 & N/A & Belgium & ins & ins & -33.4 & ins \\
\hline H. ciceri & AY045758 & N/A & IN, United States & ins & ins & -33.4 & ins \\
\hline H. ciceri $^{\mathrm{c}}$ & JX024201 & $\mathrm{FaC} 3$ & Syria & ins & ins & -33.4 & ins \\
\hline H. glycines & AY590280 & HG-G-MI & Michigan, United States & ins & ins & -33.4 & ins \\
\hline H. glycines & EF611124 & Hg1-Ark1 clone 1 & Arkansas, United States & ins & ins & -33.4 & ins \\
\hline H. hordecalis & AF274401 & N/A & United Kingdom & -32.6 & ins & ins & ins \\
\hline H. hordecalis & AF498381 & N/A & Iran & -32.6 & ins & ins & ins \\
\hline H. hordecalis & AY692356 & N/A & Indiana, United States & -19.5 & ins & ins & ins \\
\hline H. hordecalis ${ }^{\mathrm{c}}$ & AY347924 & N/A & Italy & -32.6 & ins & ins & ins \\
\hline H. iri & AF274400 & N/A & United Kingdom & -32.6 & ins & ins & ins \\
\hline H. latipons & AF498382 & N/A & Iran & -25.9 & ins & -13.0 & ins \\
\hline H. latipons & AY347925 & N/A & Russia & -25.9 & ins & -13.0 & ins \\
\hline H. latipons & HM560790 & JOD & Jordan & -25.9 & ins & -13.0 & ins \\
\hline H. latipons $\mathrm{c}^{\mathrm{c}}$ & JX024178 & Fa7A3 & Syria & -25.9 & ins & -13.0 & ins \\
\hline H. mani & AY148378 & Clone 1 & Germany & ins & ins & -36.9 & -34.1 \\
\hline H. mani & AY148375 & Clone 3 & Germany & ins & ins & -36.9 & -34.1 \\
\hline H. mani & AY692357 & N/A & United Kingdom & ins & ins & -36.9 & -34.1 \\
\hline H. pratensis & AY148351 & N/A & Russia & ins & ins & -36.9 & ins \\
\hline H. pratensis & AY148385 & Clone 1 & Germany & ins & ins & -36.9 & ins \\
\hline H. pratensis & AY148388 & Clone 1 & Netherlands & ins & ins & -36.9 & ins \\
\hline H. pratensis & AY 148391 & Clone 3 & Germany & ins & ins & -36.9 & -31.2 \\
\hline H. schachtii & EF611110 & BeM4-4 clone 3 & Belgium & ins & ins & -33.4 & ins \\
\hline H. schachtii & EF611115 & Ge2 clone 1 & Germany & ins & ins & -33.4 & ins \\
\hline H. schachtii & EF611119 & Aus 12 clone 6 & Australia & ins & ins & -33.4 & -18.0 \\
\hline H. schachtii & EF611121 & N11 clone 1 & Netherlands & ins & ins & -33.4 & -18.0 \\
\hline H. schachtii ${ }^{\mathrm{c}}$ & EF611103 & Fr1 clone 3 & France & ins & ins & -33.4 & ins \\
\hline H. turcomanica & AF498386 & N/A & Iran & ins & ins & ins & ins \\
\hline H. ustinovi & AY148405 & Clone 1 & Slovakia & -32.6 & ins & ins & ins \\
\hline H. ustinovi & AY148406 & Clone 1 & Germany & -32.6 & ins & ins & ins \\
\hline H. ustinovi & AY148407 & Clone 1 & Belgium & -32.6 & ins & ins & ins \\
\hline H. zeae & GU145616 & Clone 2304 & Greece & ins & ins & ins & -16.2 \\
\hline
\end{tabular}

a Values less than $-31 \mathrm{kcal} / \mathrm{mol}$ indicate stable primer-template formation; ins = insignificant primer-template duplex stability value predicted to have no amplification.

${ }^{\mathrm{b}}$ Name of isolates or clones obtained from GenBank; N/A = not available from GenBank.

${ }^{\mathrm{c}}$ Reference isolates tested by the species-specific PCR assays. 
$\mathrm{cm}$ in diameter by $30 \mathrm{~cm}$ deep) or 10 shovel slices $(2.5 \mathrm{~cm}$ thick, $10 \mathrm{~cm}$ wide, and $10 \mathrm{~cm}$ deep). Soil was placed into large, unsealed plastic bags which were then placed in an insulated cooler at sampling. The soil samples were transported to our laboratory and stored at $4^{\circ} \mathrm{C}$ prior to extraction of cysts.

Subsamples (1 kg each) were sent to Western Laboratories for extraction and microscopic enumeration of nematodes. Western Laboratories used a modified Oostenbrink elutriator extraction method, as described by Smiley et al. (28), and reported numbers of cyst nematodes at the genus level. The population density of $\mathrm{CCN}$ was expressed as the numbers of Heterodera spp. eggs and juveniles in $1 \mathrm{~kg}$ of soil.

Cysts were extracted from the remaining soil samples for species identification in our laboratory. Nematode DNA was extracted in triplicate from approximately 20 eggs or J2s from at least five cysts isolated from each soil sample using the abovementioned worm lysis buffer. Species-specific PCR was carried out in duplicate for each extract. The species identity was also confirmed by comparing the PCR-RFLP restriction pattern with those of known species and by examining key morphological features of the cysts, including color, underbridge in the vulval cone, semifenestrae shape, and development of bullae under a compound microscope, as described by Yan and Smiley (44). A no-DNA template was used as a negative control and DNA from the $H$. filipjevi isolate Hf1 or the H. avenae isolate Hal (Table 2) were used as positive controls.

\section{Results}

Primer specificity. The primer pair HfITS-F1/HfITS-R1 (Table 1) designed for $H$. filipjevi produced a unique PCR amplicon of 170 bp with DNA from four H. filipjevi isolates, including Hf1 from the United States and Hf2 to Hf4 from Turkey and Iran, but did not amplify DNA from $H$. avenae isolates Ha1 to Ha5 (Table 2 ). The amplicon size was deduced from the sequence of $H$. filip- jevi from Oregon (GU079654). The primer pair HaITS-F6/HaITS$\mathrm{R} 4$ designed for $H$. avenae amplified a specific band of $242 \mathrm{bp}$ with DNA from the five $H$. avenae isolates (Hal to Ha4 from the United States and Ha5 from Syria) but did not produce any amplification with DNA from the four $H$. filipjevi isolates. The amplicon size was deduced from the sequence of $H$. avenae from Idaho (EF153843). The sizes of the amplified fragments on agarose gel were in agreement with those inferred from the nucleotide sequences.

Moreover, no specific PCR product was observed when the amplification was carried out with DNA from eight nontarget Heterodera spp. (H. latipons, $H$. ciceri, $H$. glycines, $H$. goettingiana, $H$. hordecalis, H. lespedezae, $H$. schachtii, and $H$. zeae) using either the $H$. filipjevi primers (Fig. 1A) or the $H$. avenae primers (Fig. 1B). Likewise, no specific PCR amplification was produced with DNA from eight isolates of Pratylenchus spp., five isolates of Globodera spp., six isolates of Meloidogyne spp., one isolate of $N$. aberrans, and three other plant-parasitic nematode species (Tylenchorhynchus sp., M. brevidens, and Paratylenchus sp.) (Table 2). The quality of nematode DNA templates used as controls was demonstrated in Figure 1C using the universal primers D3A and D3B.

In silico analysis. The primers HfITS-F1 and HfITS-R1 are expected to form specific duplexes with the ITS sequences of three reference $H$. filipjevi isolates from the United States and Turkey based on duplex stability $(\Delta \mathrm{G})$ values (Table 3$)$. Accordingly, specific amplicons of the expected size were observed in the PCR tests. These primers are also predicted to form strong specific duplexes with the ITS sequences of six other $H$. filipjevi isolates from Spain, Germany, Russia, Tajikistan, the United Kingdom, and China. Specific amplification was reflected in $\Delta \mathrm{G}$ values of -31 $\mathrm{kcal} / \mathrm{mol}$ or less for the forward and reverse primers. The forward primer HfITS-F1 was predicted to form a hybrid with the ITS sequences of $H$. hordecalis $(\Delta \mathrm{G}=-32.6$ or -19.5$)$, H. iri $(\Delta \mathrm{G}=$

Table 4. Soil samples collected from different locations in three Pacific Northwest states and population densities of cereal cyst nematodes (CCN) and species identity determined by the species-specific polymerase chain reaction (PCR) assays

\begin{tabular}{|c|c|c|c|c|c|c|}
\hline \multirow[b]{2}{*}{ Soil name } & \multirow[b]{2}{*}{ Location } & \multirow[b]{2}{*}{ Collection date } & \multirow[b]{2}{*}{$\mathrm{CCN}_{\text {density }}{ }^{\mathrm{b}}$} & \multicolumn{2}{|c|}{ PCR assay ${ }^{a}$} & \multirow[b]{2}{*}{ Species $^{c}$} \\
\hline & & & & Heterodera avenae & H. filipjevi & \\
\hline $\mathrm{S} 1$ & Cashup, WA & August 2010 & 10,560 & + & - & H. avenae \\
\hline $\mathrm{S} 2$ & Cashup, WA & February 2012 & 2,880 & + & - & H. avenae \\
\hline S3 & Cashup, WA & June 2010 & 9,600 & + & - & H. avenae \\
\hline S4 & Colfax, WA & May 2010 & 70 & + & - & H. avenae \\
\hline S5 & Colfax, WA & June 2010 & 800 & + & - & H. avenae \\
\hline S6 & Palouse, WA & May 2010 & 4,740 & + & - & H. avenae \\
\hline S7 & Palouse, WA & May 2010 & 5,270 & + & - & H. avenae \\
\hline S8 & Steptoe, WA & February 2011 & 3,600 & + & - & H. avenae \\
\hline S9 & Steptoe, WA & February 2011 & 1,920 & + & - & H. avenae \\
\hline S10 & Steptoe, WA & June 2010 & 2,160 & + & - & H. avenae \\
\hline S11 & Cove, OR & November 2010 & 3,600 & + & - & H. avenae \\
\hline $\mathrm{S} 12$ & Cove, OR & November 2010 & 320 & + & - & H. avenae \\
\hline S13 & Cove, OR & May 2010 & 1,860 & + & - & H. avenae \\
\hline S14 & Cove, OR & February 2011 & 160 & + & - & H. avenae \\
\hline $\mathrm{S} 15$ & Cove, OR & February 2011 & 720 & + & - & H. avenae \\
\hline S16 & Imbler, OR & May 2010 & 150 & + & - & H. avenae \\
\hline S17 & Imbler, OR & November 2010 & 40 & - & + & H. filipjevi \\
\hline S18 & Imbler, OR & November 2010 & 60 & - & + & H. filipjevi \\
\hline S19 & Imbler, OR & November 2010 & 120 & - & + & H. filipjevi \\
\hline S20 & Imbler, OR & November 2010 & 160 & - & + & H. filipjevi \\
\hline S21 & Imbler, OR & November 2010 & 80 & - & + & H. filipjevi \\
\hline S22 & Imbler, OR & May 2008 & 1,110 & - & + & H. filipjevi \\
\hline S23 & Imbler, OR & May 2008 & 2,446 & - & + & H. filipjevi \\
\hline S24 & Island City, OR & October 2008 & 2,160 & + & - & H. avenae \\
\hline $\mathrm{S} 25$ & Island City, OR & October 2008 & 3,000 & + & - & H. avenae \\
\hline S26 & St. Anthony, ID & September 2010 & 14,880 & + & - & H. avenae \\
\hline S27 & St. Anthony, ID & September 2010 & 9,000 & + & - & H. avenae \\
\hline S28 & St. Anthony, ID & September 2010 & 15,480 & + & - & H. avenae \\
\hline S29 & St. Anthony, ID & September 2011 & 6,600 & + & - & H. avenae \\
\hline S30 & St. Anthony, ID & September 2011 & 8,184 & + & - & H. avenae \\
\hline
\end{tabular}

a Species identity determined by the species-specific PCR assay: $+=$ presence of the specific PCR amplicon and $-=$ absence of the specific PCR amplicon

${ }^{\mathrm{b}} \mathrm{CCN}$ density: the number of eggs and juveniles per kilogram of soil, as reported by Western Laboratories.

c Species confirmed by the PCR restriction fragment length polymorphism procedure and cyst morphology described by Yan and Smiley (44). 
-32.6), H. latipons $(\Delta \mathrm{G}=-25.9)$, and H. ustinovi $(\Delta \mathrm{G}=-32.6)$ but the reverse primer HfITS-R1 did not form a hybrid with any of these ITS sequences. Amplification from a single primer (unidirectional PCR) failed to generate enough products to be detected by PCR (17), which was supported by our experimental PCR results using the reference isolates of $H$. hordecalis from Italy and $H$. latipons from Syria. The primers were not expected to form hybrids with the ITS sequences of five reference isolates of $H$. avenae from the United States, H. ciceri from Syria, H. schachtii from France, and $H$. zeae from Greece, which is consistent with the results obtained from our PCR tests. Therefore, the $H$. filipjevi specific primers are not predicted to result in ITS amplification of any of the 51 nontarget but economically important or closely related Heterodera isolates from more than 20 countries evaluated in this study (Table 3 ).

The primers HaITS-F6 and HaITS-R4 were expected to form specific duplexes with the ITS sequences of two reference $H$. avenae isolates from the United States because of the $\Delta \mathrm{G}$ values below the stability cut-off $(-31 \mathrm{kcal} / \mathrm{mol}$; Table 3$)$. As expected, specific amplicons were observed in the PCR tests with these two reference isolates. The primers were also predicted to form specific hybrids with the ITS sequences of nine other $H$. avenae isolates from Germany, Spain, India, Turkey, Israel, Morocco, France, and China. However, both primers were predicted to form stable primer-template duplexes with the ITS sequences from one isolate of $H$. arenaria (the United Kingdom), three isolates of $H$. aucklandica (New Zealand, Belgium, and the United Kingdom), two isolates of $H$. australis (Australia), three isolates of $H$. mani (Germany and the United Kingdom), and one isolate of $H$. pratensis (Germany). Fortunately, the $H$. avenae primers were not expected to generate specific amplification with the ITS sequences from all nine $H$. filipjevi isolates and the ITS sequences from 30 nontarget isolates belonging to 10 Heterodera spp. Amplifications from a single primer HaITS-F6 with the ITS sequences from $H$. ciceri, $H$. glycines, $H$. latipons, $H$. pratensis (three of four isolates), and $H$. schachtii (two of four isolates) or from a single primer HaITS-R4 with $H$. zeae failed to generate detectable PCR products, which was supported by our experimental PCR results using the reference isolates of H. ciceri, H. latipons, H. schachtii, and H. zeae. Amplifications from both primers with two isolates of H. schachtii (EF611119 and EF611121) also failed to produce enough stable PCR products to be detected in the PCR system because the $\Delta \mathrm{G}$ value of -18.0 from

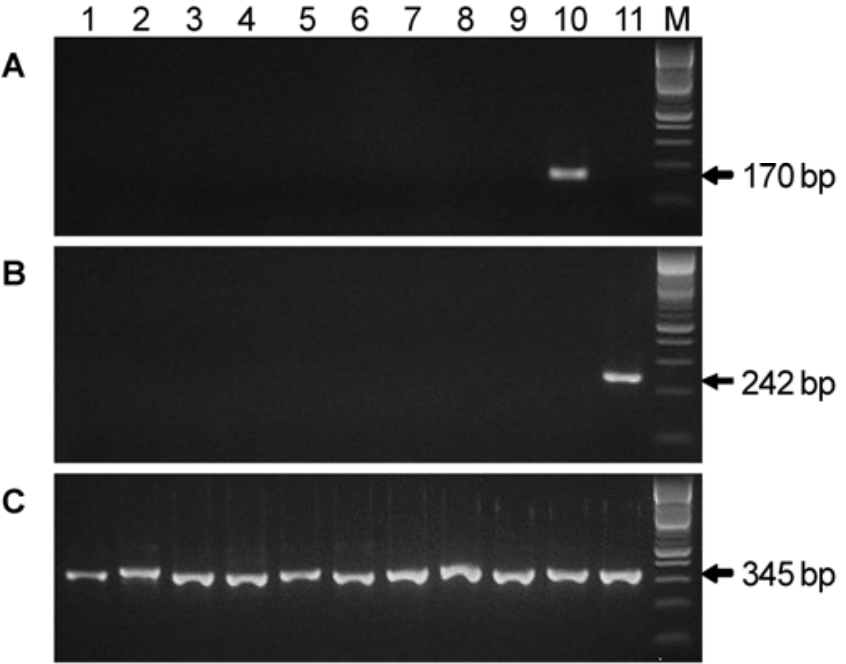

Fig. 1. Evaluation of primer specificity with control nematode species. A, Using specific primers HfITS-F1 and HfITS-R1 for Heterodera filipjevi. B, Using primers HalTS-F6 and HalTS-R4 for $H$. avenae. C, Using common primers D3A and D3B. Lane $1, H$. ciceri; lane 2, $H$. glycines; lane $3, H$. goettingiana; lane $4, H$. hordecalis; lane $5, H$. lespedezae; lane $6, H$. zeae; lane 7, Globodera pallida; lane 8, G. rostochiensis; lane 9, Meloidogyne chitwoodi; lane 10, $H$. filipjevi; lane 11, $H$. avenae; lane M, 100-bp DNA molecular weight ladder.
HaITS-R4 was relatively high and, thus, predictive of poor primertemplate binding and not expected to generate logarithmic amplification at the recommended annealing temperature (17).

Detection sensitivity of the species-specific PCR assays. Specific amplicons were obtained at all populations of eggs and $\mathrm{J} 2 \mathrm{~s}$ tested for both species. For H. filipjevi, the PCR assay detected one egg in three of the four replicated DNA extractions and one J2 in all four replicates using the worm lysis buffer. The assay detected 1:8 dilution of DNA from a single egg or $\mathbf{J} 2$ without BSA. It could detect even as low as 1:128 dilution of a single $H$. filipjevi nematode DNA by adding BSA to PCR. For $H$. avenae, the PCR test detected one egg or one $\mathrm{J} 2$ in all four DNA extractions. The assay detected 1:16 dilution of DNA from a single egg or J2 without BSA. It could detect as low as 1:128 dilution by adding BSA. Specific amplicons were also observed at a low number of $H$. filipjevi and $H$. avenae tested using the PowerSoil DNA Isolation Kit (Fig. 2). The PCR test detected 0.5 egg or $0.5 \mathrm{~J} 2$ of $H$. filipjevi in all three DNA extracts (Fig. 2A). Similarly, the PCR assay detected 0.5 egg of $H$. avenae in two of three DNA extracts and $0.5 \mathrm{~J} 2$ in all three replicated extracts (Fig. 2B). Specific amplicons were detected in all replicated DNA extractions for other levels of inoculation. No amplification was observed from the control samples without nematodes.

Distinguishing $H$. filipjevi and $H$. avenae from PNW wheat fields. The developed method was applied for detecting and discriminating $H$. filipjevi and $H$. avenae in 30 soil samples collected from wheat fields in Idaho, Oregon, and Washington. These samples harbored a range of nematode population densities, from 40 to 15,480 Heterodera spp. eggs and juveniles per kilogram of soil, based on enumerations by Western Laboratories (Table 4). Seven soil samples (S17 to S23) from different fields near Imbler, OR produced specific bands with the same size as the H. filipjevi-positive control $(170 \mathrm{bp})$ in each of the three replicated DNA extractions. These soil samples did not produce any amplification with the $H$. avenae primers. Therefore, the nematode species in these soils was identified as $H$. filipjevi. In all, 23 other soil samples (S1 to S16 and S24 to S30) from various fields near Cashup, Colfax, Palouse, and Steptoe, WA; Cove, Imbler, and Island City, OR; and St. Anthony, ID produced PCR bands with the same size as the $H$. avenae-positive control (242 bp) in all replicates, and these soil samples did not show amplification using the $H$. filipjevi-specific primers, indicating that the nematode species in these soils was $H$. avenae. The species identity in each of these soil samples was also confirmed by the PCR-RFLP restriction pattern and cyst morphology (Table 4). The banding patterns for nematode DNA from seven soil samples (S1, S8, S11, S19-S21, and S24) amplified with the specific primers are shown in Figure 3.

\section{Discussion}

Two CCN, $H$. filipjevi and $H$. avenae, were specifically detected among a range of nematode-infested soils from three PNW states

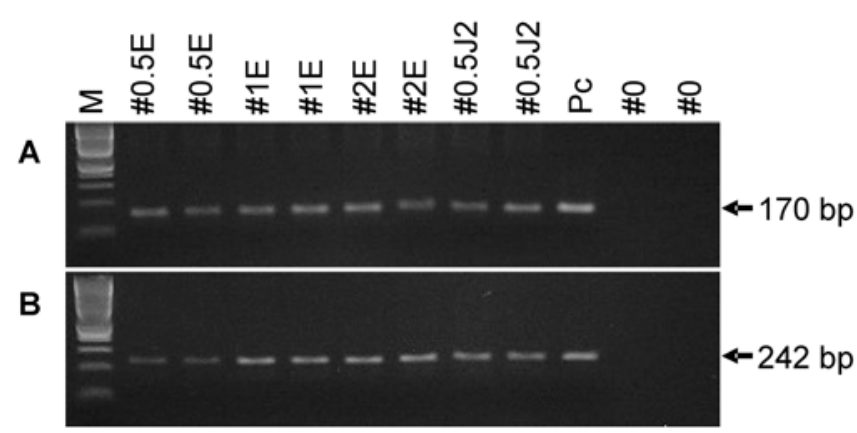

Fig. 2. Detection sensitivity of the species-specific polymerase chain reaction assays. A, Heterodera filipjevi: 0.5 egg (\#0.5E), 1 egg (\#1E), 2 eggs (\#2E), 0.5 second-stage juvenile (\#0.5J2), positive control of $H$. filipjevi $(\mathrm{Pc})$, and negative control (\#0). B, H. avenae: 0.5 egg (\#0.5E), 1 egg (\#1E), 2 eggs (\#2E), 0.5 secondstage juvenile (\#0.5J2), positive control of $H$. avenae $(\mathrm{Pc})$, and negative control (\#0). M: 100-bp DNA ladder. 
(Idaho, Oregon, and Washington) and in isolates from three other countries (Iran, Syria, and Turkey) using the assays developed in this study. The assays were sensitive because they were able to detect a single egg or $\mathrm{J} 2$ using a laboratory-made lysis buffer, or 0.5 egg or $\mathrm{J} 2$ using a commercial kit. The assay for $H$. filipjevi was proven to be highly specific when tested with template DNA from 41 isolates of Heterodera spp. and non-Heterodera species, including plant-parasitic nematode species commonly present in PNW wheat fields. The primer pair for $H$. filipjevi was also predicted to be highly specific by in silico analysis using the ITS sequences from 60 isolates of closely related or economically important Heterodera spp. from more than 20 countries. To our knowledge, this is the first report of a species-specific ITS PCR method for detection and identification of $H$. filipjevi.

The predictions obtained from in silico analysis are consistent with the results obtained in our PCR tests with the 10 reference isolates of $H$. filipjevi, $H$. avenae, $H$. latipons, $H$. hordecalis, $H$. schachtii, $H$. ciceri, and $H$. zeae. In silico analysis was then applied to 50 other isolates of Heterodera spp. that could not be obtained in culture or DNA upon request to predict the specificity of the primers. The primer pair for $H$. filipjevi was more specific than that of $H$. avenae, based on predicted amplification of the latter to DNA of five Heterodera spp. (H. arenaria, H. aucklandica, H. australis, $H$. mani, and $H$. pratensis). In silico analysis has been previously used to predict the specificity of PCR primers for diagnostics of Asiatic citrus canker disease (Xanthomonas citri pv. citri), rootlesion nematodes ( $P$. thornei and $P$. neglectus), Rhizoctonia root rot (Rhizoctonia solani and $R$. oryzae), and Pythium root rot (Pythium spp.) $(6,17,24,45-47)$. Delcourt et al. (6) reported that sequence analyses conducted in silico from public databases for diagnostics of $X$. citri pv. citri was very informative and useful, and should be performed to efficiently evaluate primer specificity because an increasing number of sequences are now available from GenBank, which is fully supported by our findings for diagnostics of the two cyst nematode species $H$. filipjevi and $H$. avenae.

The species-specific primers were designed from the variable ITS-rDNA sequences of Heterodera spp. The ITS region was thought to be variable and, therefore, useful for nematode identification at species level $(5,23,48)$. Yan and Smiley (44) reported that six restriction endonucleases (TaqI, HinfI, PstI, HaeIII, RsaI, and $A l u \mathrm{I})$ and their combinations used for PCR-RFLP based on the ITS region allowed for distinguishing $H$. avenae and $H$. filipjevi, and for separating these two species from $H$. arenaria, $H$. hordecalis, H. latipons, H. mani, H. pratensis, and $H$. schachtii. The PCR assay specific for $H$. filipjevi is preferred over the PCR-RFLP analysis, because this PCR assay is expected to successfully differentiate $H$. filipjevi in one-step PCR, without additional steps of RFLP analysis and combination of multiple enzyme digestions, from all the above species evaluated by the PCR-RFLP and from all other Heterodera spp. evaluated in this study.

The PCR assay for $H$. avenae successfully differentiated $H$. avenae from $H$. filipjevi and $H$. latipons (two other economically important $\mathrm{CCN}$ ), $H$. glycines and $H$. schachtii (two very widespread and economically important cyst nematodes), $H$. hordecalis (a closely related species in the H. avenae group), four other Heterodera spp., and all non-Heterodera species in our tests. However, in silico analysis predicted cross reactivity between the $H$. avenae primers and the sequences of $H$. arenaria, $H$. aucklandica, $H$. australis, $H$. mani, and one isolate of $H$. pratensis due to the lack of polymorphisms in the ITS sequences between these species. $H$. arenaria, $H$. aucklandica, $H$. australis, and $H$. pratensis that occur in other countries have not been reported in the United States $(33,44)$. To our knowledge, $H$. mani was reported in the United States but has not been found in the PNW. H. mani also does not reproduce readily on wheat, oat, and barley (33). Therefore, cross reactions of the primers with the five species should not interfere with the diagnosis of $H$. avenae in the PNW fields in which all of these five species are currently absent. Although Toumi et al. (38) developed species-specific primer sets to detect $H$. avenae and $H$. filipjevi on the basis of the COI gene and Peng et al. (20) devel- oped species-specific SCAR-PCR assays to detect $H$. filipjevi, these five species were not included in their tests, except that one isolate of $H$. pratensis from Belgium was examined by Toumi et al. (38). Four isolates of $H$. pratensis from Germany, the Netherlands, and Russia evaluated in our study were not tested by their assays.

A duplex PCR was attempted for differentiating these nematodes but, as a result, it was not suitable for identifying mixtures of these two species. The primer pairs for both species were mixed in the same PCR reactions. When tested with pure DNA from only one species, specific amplifications occurred and the species could be accurately identified. However, when tested with mixed DNA from equal amounts of DNA from these two species, $H$. avenae produced strong amplification but $H$. filipjevi had very weak amplification, indicating that the two primer pairs were not suitable in a duplex PCR for identifying mixed populations of these two species. This was probably due to the big difference in annealing temperatures, $58^{\circ} \mathrm{C}$ for the $H$. filipjevi primers and $64^{\circ} \mathrm{C}$ for the $H$. avenae primers.

Both primer pairs used in separate PCR reactions detected a single egg or $\mathrm{J} 2$ using a laboratory-made lysis buffer and detected 0.5 egg or $0.5 \mathrm{~J} 2$ using a commercial kit. They could detect even as low as 1:128 dilution of DNA from a single egg or $\mathrm{J} 2$ for both species by adding BSA to PCR. This detection sensitivity was higher than those reported for cyst nematodes. Subbotin et al. (32) described a PCR method with species-specific primers for rapid identification of the soybean cyst nematode $H$. glycines and was able to detect a single cyst or J2. Ou et al. (19) designed speciesspecific SCAR primers to amplify DNA from a single J2 or female of $H$. glycines. Peng et al. (20) detected 1:8 dilution of DNA from a single $\mathrm{J} 2$ of $H$. filipjevi using the SCAR-PCR assays. Toumi et al. (38) could detect $0.5 \mathrm{~J} 2$ of $H$. avenae or $H$. filipjevi among $100 \mathrm{~J} 2 \mathrm{~s}$ of $H$. latipons using species-specific primers designed from the COI gene. BSA, as a PCR enhancer, greatly improved the detection of $H$. filipjevi and $H$. avenae, which was supported by our reports for detection and quantification of the root-lesion nematode $P$. neglectus from soil $(46,47)$.

The end-point PCR primers were tested to determine whether they were directly applicable in a SYBR Green I-based real-time PCR format. The $H$. filipjevi primers produced specific amplification from DNA templates of all isolates of $H$. filipjevi and did not produce specific amplification from all isolates of $H$. avenae and nontarget nematode species tested in this study. The mean cycle threshold $(\mathrm{Ct})$ values for $1 \mathrm{~J} 2,1 \mathrm{egg}$, and 26 eggs were 33.70 , 33.45 , and 27.48 , respectively. The primers for $H$. avenae generated specific amplification from DNA templates of all isolates of $H$. avenae, and did not generate specific amplification from all isolates of $H$. filipjevi. The mean $\mathrm{Ct}$ value for $26 \mathrm{H}$. avenae eggs was 22.47. However, these primers consistently produced secondary peaks in melting curve analyses, leading to overestimation of

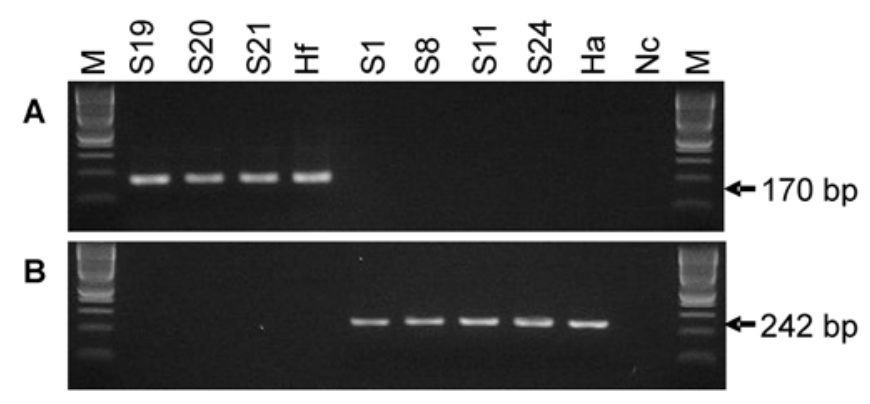

Fig. 3. Specific polymerase chain reaction (PCR) amplification using DNA from cysts isolated from field soils in the Pacific Northw4est. A, PCR bands (170 bp) amplified with primers HfITS-F1 and HfITS-R1 for Heterodera filipjevi. B, PCR bands (242 bp) amplified with primers HalTS-F6 and HalTS-R4 for $H$. avenae. DNA templates from the soil samples S1, S8, S11, S19, S20, S21, and S24 (Table 4) in Washington, Oregon, and Idaho were used. $\mathrm{Hf}$ : the $H$. filipjevi isolate ( $\mathrm{Hf} 1$, Table 2) used as a positive control; $\mathrm{Ha}$ : the $H$. avenae isolate (Ha1, Table 2) used as a positive control; and Nc: negative control without DNA template. M: 100-bp DNA molecular weight ladder. 
the target nematodes. We tested several other primer pairs designed from the same ITS regions but they were also not suitable for quantification. This might be due to the greater sensitivity of the real-time PCR method compared to the end-point PCR with agarose gel electrophoresis. The same scenario also occurred when we applied the end-point PCR primers to the real-time PCR for quantifying $P$. neglectus and $P$. thornei (45-47). Therefore, SYBR Green real-time PCR using a different DNA region than ITS-rDNA or TaqMan real-time PCR would have to be developed for detection and quantification of $H$. avenae and $H$. filipjevi from infested soil.

The species-specific PCR assays identified all the tested $H$. filipjevi and $H$. avenae populations that originated from three states in the PNW. To our knowledge, this is the first report of specific ITS PCR primers for distinguishing $H$. avenae and $H$. filipjevi. Mixed populations of these two species were not detected in the field samples used in this study. One possible reason is that $H$. avenae is more widely distributed than $H$. filipjevi in this region and the occurrence of mixed species is not common. Another reason could be that both species may occur in a single field but our samples might have skipped the sites that contained mixed populations. Our previous research with grid soil sampling demonstrated that $\mathrm{CCN}$ were unevenly distributed in a field (44).

Species identification is important for recommending and implementing effective management practices. Currently, practices for managing cereal cysts nematodes are limited (29). There are no registered chemical or biological controls that are effective for reducing populations of these cyst nematodes and increasing yields of wheat in the PNW. Rotations of wheat with multiple years of broadleaf crops or bare fallow reduce population densities and improve wheat yields compared with annual wheat (26) but crop rotations do not allow sufficiently intensive wheat production and, therefore, are generally not profitable for PNW wheat producers. The use of wheat cultivars that are both resistant and tolerant is the best approach to control damage from these nematodes (25). Lately, Smiley et al. (27) identified one commercial wheat cultivar and four breeding lines with resistance to $H$. avenae in naturally infested fields in the PNW but the resistance reactions to $H$. filipjevi were unknown. However, overseas research indicated that individual wheat cultivars could differ in their ability to resist these two nematodes; a cultivar exhibiting resistance to $H$. avenae was not necessarily resistant to $H$. filipjevi, and vice versa (16). Therefore, accurate identification of these two species in each field or region is important for selecting the best-performing cultivars to maintain high crop production.

The developed PCR assays will enable research and commercial laboratories to rapidly and efficiently diagnose the threat from individual species of $\mathrm{CCN}$ and facilitate systematic nematode surveys to investigate the geographic distribution of $H$. filipjevi in the western United States. This diagnostic capability is expected to become increasingly important as grain growers become more aware of damage from these root parasites, and as wheat cultivars with effective resistance genes are developed and planted in highly infested fields in the PNW.

\section{Acknowledgments}

This research was supported by the Idaho Wheat Commission, Oregon Wheat Commission, and Washington Grains Commission; Oregon State University, Agricultural Research Foundation project ARF 7136A; and a subcontract between Oregon State University and the United States Department of Agriculture-Agricultural Research Service (SCA 58-5348-9-100, "Control of Root Diseases of Wheat and Barley"). We thank L. Waeyenberge and F. Toumi (Plant Sciences Unit-Crop Protection, Merelbeke, Belgium) and R. Rivoal (INRA, Rennes, France) for providing DNA standards of control specimens of Heterodera spp.; growers who allowed us to collect soil samples from their properties; scientists who assisted with collection of samples in Idaho (J. Marshall) and Washington (T. Paulitz); and Western Laboratories (Parma, ID) for providing discounted costs for cyst nematode enumeration services.

\section{Literature Cited}

1. Abidou, H., Valette, S., Gauthier, J. P., Rivoal, R., El-Ahmed, A., and Yahyaoui, A. 2005. Molecular polymorphism and morphometrics of species of the Heterodera avenae group in Syria and Turkey. J. Nematol. 37:146154.

2. Al-Banna, L., Ploeg, A. T., Williamson, V. M., and Kaloshian, I. 2004. Discrimination of six Pratylenchus species using PCR and species-specific primers. J. Nematol. 36:142-146.

3. Al-Banna, L., Williamson, V., and Gardner, S. L. 1997. Phylogenetic analysis of nematodes of the genus Pratylenchus using nuclear $26 \mathrm{~S}$ rDNA. Mol. Phylogenet. Evol. 7:94-102.

4. Amiri, S., Subbotin, S. A., and Moens, M. 2002. Identification of the beet cyst nematode Heterodera schachtii by PCR. Eur. J. Plant Pathol. 108:497506.

5. Bekal, S., Gauthier, J. P., and Rivoal, R. 1997. Genetic diversity among a complex of cereal cyst nematodes inferred from RFLP analysis of the ribosomal internal transcribed spacer region. Genome 40:479-486.

6. Delcourt, S., Vernière, C., Boyer, C., Pruvost, O., Hostachy, B., and Robène-Soustrade, I. 2013. Revisiting the specificity of PCR primers for diagnostics of Xanthomonas citri pv. citri by experimental and in silico analyses. Plant Dis. 97:373-378. Online publication. http://dx.doi.org/10.1094/ PDIS-04-12-0351-RE

7. Hafez, S. L., and Golden, A. M. 1984. First report of oat cyst nematode in eastern Washington. (Abstr.) Plant Dis. 68:351.

8. Hafez, S. L., and Golden, A. M. 1985. First report of oat cyst nematode (Heterodera avenae) on barley in Idaho. (Abstr.) Plant Dis. 69:360.

9. Hafez, S. L., Golden, A. M., Rashid, F., and Handoo, Z. 1992. Plant-parasitic nematodes associated with crops in Idaho and eastern Oregon. Nematropica 22:193-204.

10. Handoo, Z. A. 2002. A key and compendium to species of the Heterodera avenae Group (Nematoda: Heteroderidae). J. Nematol. 34:250-262.

11. Hollaway, G. J., Ophel-Keller, K. M., Taylor, S. P., Burns, R. A., and McKay, A. C. 2003. Effect of soil water content, sampling method and sample storage on the quantification of root-lesion nematodes (Pratylenchus spp.) by different methods. Australas. Plant Pathol. 32:73-79.

12. Ingham, R. E. 1994. Nematodes. Pages 459-490 in: Methods of Soil Analysis Part 2. Microbiological and Biochemical Properties. R. W. Weaver, J. S Angle, and P. S. Bottomley, eds. Soil Science Society of America, Madison, WI.

13. Jensen, H. J., Eshtiaghi, H., Koepsell, P. A., and Goetze, N. 1975. The oat cyst nematode, Heterodera avenae, occurs on oats in Oregon. Plant Dis. Rep. 59:1-3.

14. Madani, M., Vovlas, N., Castillo, P., Subbotin, S. A., and Moens, M. 2004 Molecular characterization of cyst nematode species (Heterodera spp.) from the Mediterranean Basin using RFLPs and sequences of ITS-rDNA. J. Phytopathol. 152:229-234.

15. McDonald, A. H., and Nicol, J. M. 2005. Nematode parasites of cereals Pages 131-191 in: Plant Parasitic Nematodes in Subtropical and Tropical Agriculture. M. Luc, R. A. Sikora, and J. Bridge, eds. CAB International, Wallingford, UK.

16. Mokabli, A., Valette, S., Gauthier, J.-P., and Rivoal, R. 2002. Variation in virulence of cereal cyst nematode populations from North Africa and Asia. Nematology 4:521-525.

17. Okubara, P. A., Schroeder, K. L., and Paulitz, T. C. 2008. Identification and quantification of Rhizoctonia solani and $R$. oryzae using real-time polymerase chain reaction. Phytopathology 98:837-847.

18. Ophel-Keller, K., McKay, A., Hartley, D., Herdina, and Curran, J. 2008. Development of a routine DNA-based testing service for soilborne diseases in Australia. Australas. Plant Pathol. 37:243-253.

19. Ou, S., Peng, D., Liu, X., Li, Y., and Moens, M. 2008. Identification of Heterodera glycines using PCR with sequence characterised amplified region (SCAR) primers. Nematology 10:397-403.

20. Peng, H., Qi, X., Peng, D., Long, H., He, X., Huang, W., and He, W. 2013. Sensitive and direct detection of Heterodera filipjevi in soil and wheat roots by species-specific SCAR-PCR assays. Plant Dis. 97:1288-1294.

21. Riley, I. T., Nobbs, J. M., Herdina, and McKay, A. C. 2009. Pratylenchus species in pastures in the South East Region of South Australia. Australas. Plant Dis. Notes 4:89-90.

22. Rivoal, R., and Cook, R. 1993. Nematode pests of cereals. Pages 259-303 in: Plant Parasitic Nematodes in Temperate Agriculture. K. Evans, D. L. Trudgill, and J. M. Webster, eds. CAB International, Wallingford, UK.

23. Rivoal, R., Valette, S., Bekal, S., Gauthier, J.-P., and Yahyaoui, A. 2003 Genetic and phenotypic diversity in the graminaceous cyst nematode complex, inferred from PCR-RFLP of ribosomal DNA and morphometric analysis. Eur. J. Plant Pathol. 109:227-241.

24. Schroeder, K. L., Okubara, P. A., Tambong, J. T., Lévesque, C. A., and Paulitz, T. C. 2006. Identification and quantification of pathogenic Pythium spp. from soils in eastern Washington using real-time polymerase chain reaction. Phytopathology 96:637-647.

25. Smiley, R. W. 2009. Occurrence, distribution and control of Heterodera avenae and $H$. filipjevi in the western USA. Pages 35-40 in: Proc. 1st Int Cereal Cyst Nematodes Initiative. I. T. Riley, J. M. Nicol, and A. A. Dababat, eds. CIMMYT, Ankara, Turkey.

26. Smiley, R. W., Ingham, R. E., Uddin, W., and Cook, G. H. 1994. Crop sequences for managing cereal cyst nematode and fungal pathogens of winter wheat. Plant Dis. 78:1142-1149.

27. Smiley, R. W., Marshall, J. M., Gourlie, J. A., Paulitz, T. C., Kandel, S. L., 
Pumphrey, M. O., Garland Campbell, K., Yan, G. P., Anderson, M. D., Flowers, M. D., and Jackson, C. A. 2013. Spring wheat tolerance and resistance to Heterodera avenae in the Pacific Northwest. Plant Dis. 97:590600.

28. Smiley, R. W., Marshall, J. M., and Yan, G. P. 2011. Effect of foliarly applied spirotetramat on reproduction of Heterodera avenae on wheat roots. Plant Dis. 95:983-989.

29. Smiley, R. W., and Nicol, J. M. 2009. Nematodes which challenge global wheat production. Pages 171-187 in: Wheat Science and Trade. B. F. Carver, ed. Wiley-Blackwell Publishers, Ames, IA.

30. Smiley, R. W., Whittaker, R. G., Gourlie, J. A., Easley, S. A., and Ingham, R. E. 2005. Plant-parasitic nematodes associated with reduced wheat yield in Oregon: Heterodera avenae. J. Nematol. 37:297-307.

31. Smiley, R. W., Yan, G. P., and Handoo, Z. A. 2008. First record of the cyst nematode Heterodera filipjevi on wheat in Oregon. Plant Dis. 92:1136.

32. Subbotin, S. A., Peng, D., and Moens, M. 2001. A rapid method for the identification of the soybean cyst nematode Heterodera glycines using duplex PCR. Nematology 3:365-371.

33. Subbotin, S. A., Sturhan, D., Rumpenhorst, H. J., and Moens, M. 2003. Molecular and morphological characterisation of the Heterodera avenae species complex (Tylenchida: Heteroderidae). Nematology 5:515-538.

34. Subbotin, S. A., Waeyenberge, L., and Moens, M. 2000. Identification of cyst forming nematodes of the genus Heterodera (Nematoda: Heteroderidae) based on the ribosomal DNA-RFLPs. Nematology 2:153-164.

35. Subbotin, S. A., Waeyenberge, L., Molokanova, I. A., and Moens, M. 1999. Identification of Heterodera avenae group species by morphometrics and rDNA-RFLPs. Nematology 1:195-207.

36. Tanha Maafi, Z., Subbotin, S. A., and Moens, M. 2003. Molecular identification of cyst-forming nematodes (Heteroderidae) from Iran and a phylogeny based on ITS-rDNA sequences. Nematology 5:99-111.

37. Toumi, F. F. 2010. Development of a species-specific PCR to detect the cereal cyst nematode Heterodera latipons. M.S. thesis, Ghent University, Ghent, Belgium.

38. Toumi, F., Waeyenberge, L., Viaene, N., Dababat, A., Nicol, J. M., Ogbonnaya, F., and Moens, M. 2013. Development of two species-specific primer sets to detect the cereal cyst nematodes Heterodera avenae and Heterodera filipjevi. Eur. J. Plant Pathol. Online publication. doi:10.1007/s10658-013 0192-9

39. Vrain, T. C., Wakarchuk, D. A., Lévesque, A. C., and Hamilton, R. I. 1992 Intraspecific rDNA restriction fragment length polymorphism in the Xiphinema americanum group. Fundam. Appl. Nematol. 15:563-573.

40. Waeyenberge, L., Ryss, A., Moens, M., Pinochet, J., and Vrain, T. C. 2000 Molecular characterization of 18 Pratylenchus species using rDNA restriction fragment length polymorphism. Nematology 2:135-142.

41. Wendt, K. R., Vrain, T. C., and Webster, J. M. 1993. Separation of three species of Ditylenchus and some host races of D. dipsaci by restriction fragment length polymorphism. J. Nematol. 25:555-563.

42. Wouts, W. M., and Baldwin, J. G. 1998. Taxonomy and identification. Pages 83-122 in: The Cyst Nematodes. S. B. Sharma, ed. Kluwer Academic Publishers, London.

43. Yan, G. P., and Smiley, R. W. 2009. Discovery of Heterodera filipjevi on wheat in the USA. Pages 94-99 in: Proc. 1st Int. Cereal Cyst Nematodes Initiative. I. T. Riley, J. M. Nicol, and A. A. Dababat, eds. CIMMYT, Ankara, Turkey.

44. Yan, G. P., and Smiley, R. W. 2010. Distinguishing Heterodera filipjevi and $H$. avenae using polymerase chain reaction-restriction fragment length polymorphism and cyst morphology. Phytopathology 100:216-224.

45. Yan, G. P., Smiley, R. W., and Okubara, P. A. 2012. Detection and quantification of Pratylenchus thornei in DNA extracted from soil using real-time PCR. Phytopathology 102:14-22.

46. Yan, G. P. Smiley, R. W., Okubara, P. A Skantar, A. M., Easley, S. A Sheedy, J. G., and Thompson, A. L. 2008. Detection and discrimination of Pratylenchus neglectus and $P$. thornei in DNA extracts from soil. Plant Dis. 92:1480-1487.

47. Yan, G. P., Smiley, R. W., Okubara, P. A., Skantar, A. M., and Reardon, C. L. 2013. Developing a real-time PCR assay for detection and quantification of Pratylenchus neglectus in soil. Plant Dis. 97:757-764.

48. Zijlstra, C., Lever, A. E. M., Uenk, B. J., and Van Sil Fhout, C. H. 1995. Differences between ITS regions of isolates of root-knot nematodes $\mathrm{Mel}$ oidogyne hapla and M. chitwoodi. Phytopathology 85:1231-1237. 